\title{
Restoration of Bare Incrusted Soils in the Sahel Region of Burkina Faso
}

\author{
Marco Schmidt, Konstantin König, Karen Hahn, Georg Zizka, Rüdiger Wittig
}

Abstract: Bare incrusted soils are a degradation stage often encountered in the Sahel zone. Our study documents the success of restoration (= regreening) experiments using deep ploughing in an experimental site south of Gorom-Gorom in the Oudalan province of Burkina Faso. We used phytosociological relevés and maximum likelihood classifications of digital photography to analyze changes in vegetation. Plant cover in treated plots was found to be about 20 times higher than in control plots, mean species richness more than twice as high. Therefore, this promising restoration method should be tested also in other Sahelian regions. Our approach to combine phytosociological relevés and maximum likelihood classifications of digital photography proved to be very useful.

Key words: biodiversity, rangeland regeneration, soil crusts, Vallerani system

\section{Restoration des sols nus encroûtés dans la RÉgion du SaHEl du BuRKina Faso}

Résumé: Un sol nu et encroûté est un stade de dégradation souvent rencontré dans la région du Sahel. Notre étude, effectuée dans un site expérimental au sud de Gorom-Gorom dans la province d'Oudalan au Burkina Faso, documente le succès de restauration (= reverdissement) dû aux labours profonds. A cette fin, nous avons utilisés des relevés phytosociologiques ainsi que des classifications, basées sur le maximum de vraisemblance, de photographies digitales. Dans les parcelles non traitées, le couvert végétal était environ vingt fois plus élevé que dans les parcelles contrôles. En outre la richesse spécifique moyenne dépassait de plus du double celle des contrôles. Nos résultats sont prometteurs, la methode devrait être évalué dans d'autres régions saheliens aussi. Notre combinaison des relevés phytosociologiques avec une classification de maximum de vraisemblance des photos numériques à prouvé son utilité.

Mots clés: biodiversité, régéneration de pâturages, encroûtement du sol, systeme Vallerani

\section{Restoration nackter Bodenkrusten in der Sahelzone von Burkina Faso}

Zusammenfassung: Nackte Krusten stellen in der Sahelzone ein oft gefundenes Degenerationsstadium von Böden dar. Unsere Untersuchung dokumentiert den Erfolg von Restorations(Wiederbegrünungs)versuchen mittels Tiefpflügen auf einer Versuchsfläche südlich von Gorom-Gorom (Provinz Oudalan, Burkina Faso). Zur Analyse der Wiederbegrünung nutzten wir pflanzensoziologische Aufnahmen und maximum likelihood Klassifikationen digitaler Fotos. In den gepflügten Flächen war die Vegetationsbedeckung zwanzigmal höher als in den Kontrollflächen und die mittlere Artenzahl mehr als doppelt so hoch. Diese vielversprechende Restorationsmethode sollte daher auch in anderen Regionen der Sahelzone erprobt werden. Unser Ansatz der Kombination pflanzensoziologischer Methoden mit maximum likelihood Klassifikationen digitaler Fotos erwies sich als sehr nützlich.

Schlagworte: Biodiversität, Bodenkrusten, Weideland Regeneration, Vallerani System

\section{INTRODUCTION}

The trans-African belt of the Sahel is located at the southern fringe of the Sahara, the world's largest desert. The vegetation in its North is characterized by annuals and herbaceous perennials, while the South is dominated by Acacia savannas (WHITE 1983). Although some agriculture is possible in areas with a comparably good water availability (e.g. millet on dunes), the main land use is animal husbandry, usually pastoralism with cattle and small ruminants (Fig. 1). In the Oudalan province and the entire Sahel region of Burkina Faso, grazing pressure and resulting erosion has led to the formation of bare incrusted soils called zipellé in Burkina Faso or hardé in Chad (Zougmoré et al. 2003).

These soils have a reduced permeability for water which prevents their regreening. To break out of this vicious circle, different approaches have been developed, including termite- and mulch-mediated rehabilitation (MANDO et al. 1999), the Zaï system (Roose et al. 1999; GANABA et al. 2006; SAWADOGO et al. 2008) and the Vallerani system (PARI \& ANTINORI 2001; MALAGNOUX 2009). Here we present a case study documenting the restoration success resulting from the application of the latter system in the Sahelian region of Burkina Faso. The aim of the experiment was to regreen the bare crusts, i.e. increase plant cover in as short time as possible by simple and locally available means.

\section{Methods}

The study area is situated in the province of Oudalan (Burkina Faso), south of Gorom-Gorom, near the road to Dori. There the rainy season lasts three to four months. In the last decade, average annual rainfall in this area was found to be between 400 and $500 \mathrm{~mm}$ (WITTIG et al. 2006), showing great local and interannual variation. In the year of investigation, an annual precipitation amount of c. $600 \mathrm{~mm}$ was observed (supplementary material to NIELSEN \& REENBERG 2010).

The incrusted soils are found in the glacis area. The natural vegetation of the glacis is formed by thornbush savannas and tigerbush, a mosaic of dense shrubby vegetation and bare soil, appearing on slight slopes and certain soil conditions. Today in Burkina Faso, tigerbush only remains in re- 


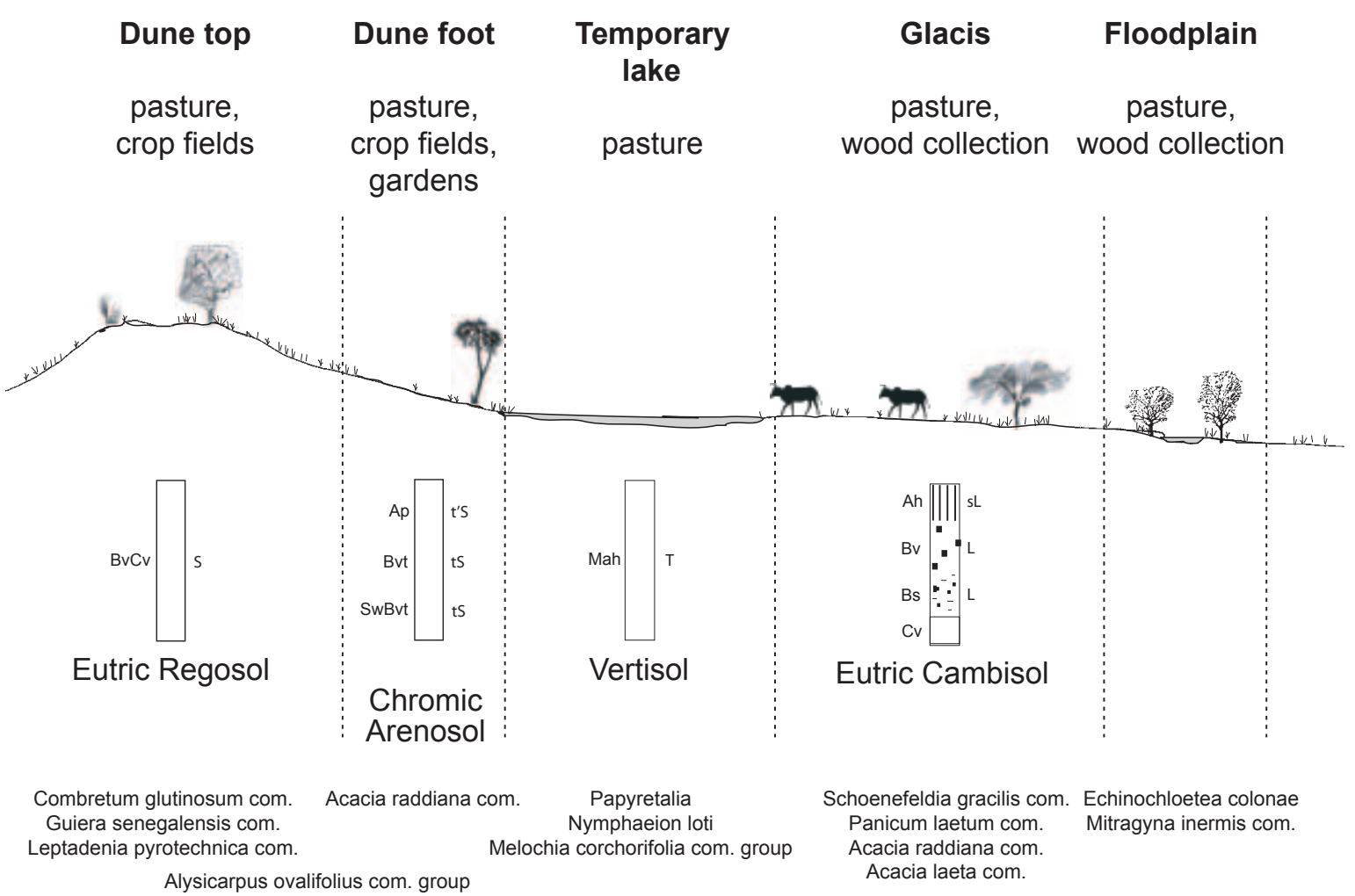

Fig. 1: Generalised profile of the Sahelian landscape in northern Burkina Faso (from WitTIG et al. 2002; amplified and translated into English); vegetation: selected dominant units (for more details see MÜLLER 2003, OUEDRAOGO et al. 2005)

Fig. 1: Profile généralisé du paysage sahélien au nord du Burkina Faso; végétation: unités dominantes sélectionnées.

mote areas. In the vicinity of settlements it has totally disappeared due to overexploitation. In these areas, not incrusted soils are covered by the Schoenefeldia gracilis community with a coverage of 70 to $90 \%$ (MÜLLER 2003). On incrusted soils however, vegetation cover is generally below $5 \%$.

Due to locally varying transport and accumulation processes, the soils of the glacis are very inhomogeneous. Soil incrustion is caused by sheet wash which leads to the formation of run-off crusts. Incrusted soils show only very little infiltration (ALBERT et al. 2004). Moreover, the small part of the precipitation that is infiltrated is not available for plants but strongly retained in the micropores of the argillaceous material (CLAUdE et al. 1991). As long as an intact tiger bush exists, runoff is retained by the bush stripes which usually grow perpendicular to the sheet flow direction.

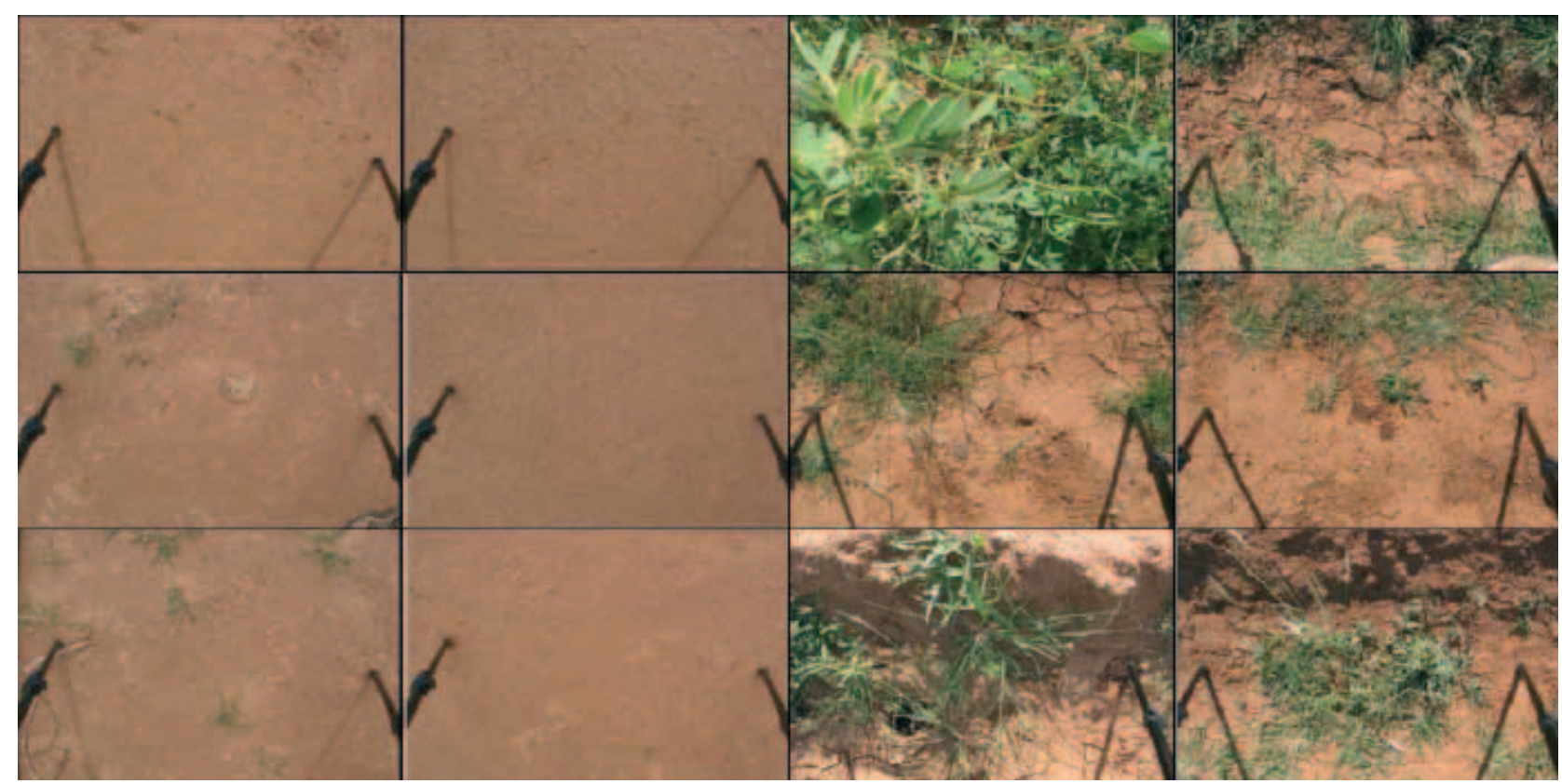

Fig. 2: Photographic records of restoration treatment (right) and control plot (left).

Fig. 2: Documentation photographique des placeaux de restoration (droite) et contrôles (gauche). 


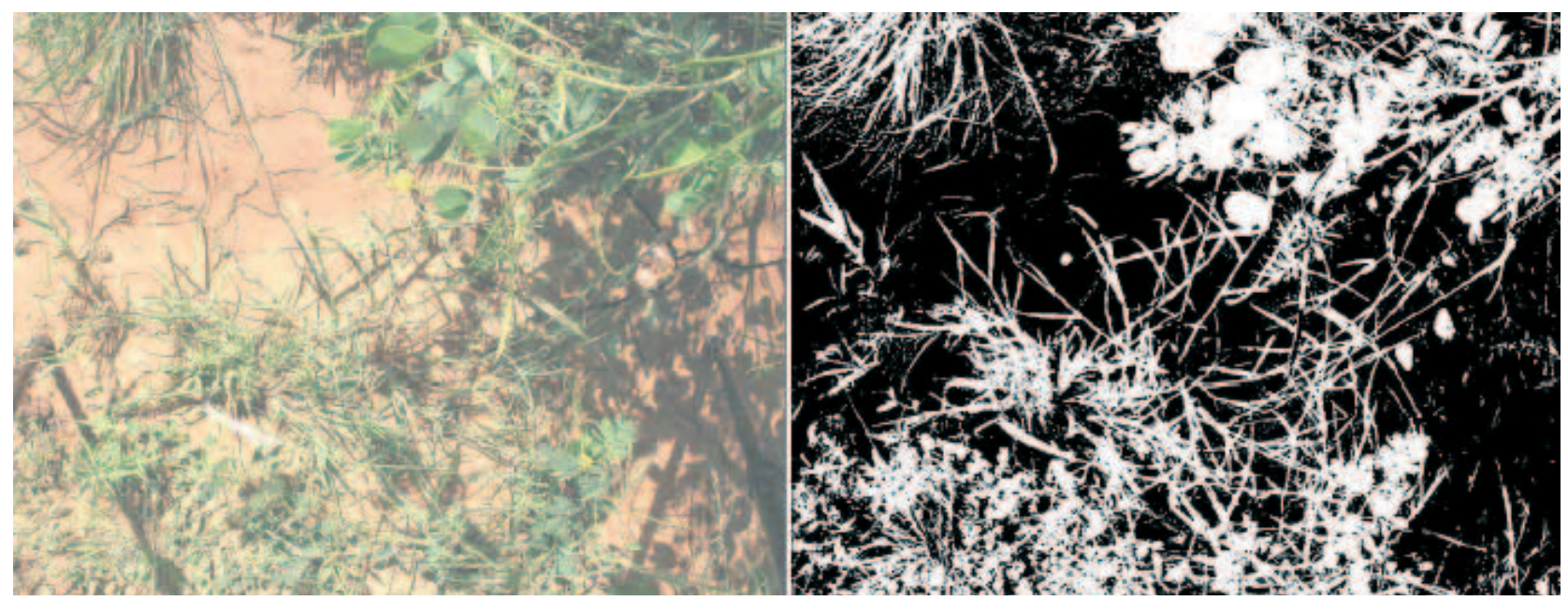

Fig. 3: Digital photo (left side) classified in vegetation and bare soil with a maximum likelihood algorithm (right side).

Fig. 3: Photo numérique (gauche) classifiée en végétation et sol nu avec un algorithme de maximum de vraisemblance (droite).

At the beginning of the rainy season of the year 2002, a degraded glacis was partly deep-ploughed by ADRA GoromGorom (Adventist Development and Relief Agency) using the particular ploughs that are characteristic of the Vallerani system. The remaining part was left undisturbed for control. Although animals were supposed to be excluded from the area, we observed some goats drinking from the puddles of the plough traces. We randomly placed ten rectangular plots (size $5.0 \mathrm{~m} \times 3.5 \mathrm{~m}$ ), both in the ploughed and the control area. In the deep ploughed area the longer side of the rectangles ran along the direction of the plough lines, the shorter side perpendicular to these, with the plough line exactly in its centre. We recorded plant cover for each species in percent, since the often used cover classes of BRAUN-BLANQUET (1964) or of LONDO (1976) would not have been suitable for the description of the very sparse vegetation and consequently would have corrupted our results.

Within the area of the botanical relevé we randomly placed five digital photos at a height of $1 \mathrm{~m}$ from the ground and a standard focal length (Fig. 2). A maximum likelihood algorithm was used to classify the pixels into vegetation and bare soil (Fig. 3). We tested the classification with visual verification of 1000 random pixels and had an error rate of only $0,3 \%$.

Relevé data was stored in VegDa (SCHMIDT 2006). Similarity in species composition among relevés was analyzed with cluster analysis using PCORD 5.0. Sørensen coefficient (SøRENSEN 1948) was used as similarity measure and clusters were defined by the flexible beta grouping method with $\beta=-0.25$. Diagnostic species were identified using the fidelity measure $\varphi$ (fidelity*100) that compares the frequency of a species within a group with the constancy of the same species in all other groups within the dataset. All diagnostic species had $\varphi$-value higher than 30 and significance $\mathrm{p}<0.05$ according to Fisher's Exact Test.

Differences in the number of species and evenness, as measure for equitability (PIELOU 1969); between ploughed and unploughed sites were compared with Univariate Analysis of Variance (ANOVA) using the software SPSS 15 (SPSS Inc., Chicago IL, USA)

\section{RESULtS}

Vegetation cover and species richness were significantly higher $(p<0.001)$ in deep plough treated plots than in the control plots: the mean vegetation cover was approximately 20 times higher (Fig. 4), mean species richness more than twice as high (Fig. 5). Also evenness is significantly higher in the ploughed plots $(\mathrm{p}<0.001)$.



Fig. 4: Vegetation cover (\%) in deep ploughed and control plots. $\mathrm{N}=50$, error bars indicate $95 \%$ confidence intervals.

Fig. 4: Recouvrement de végétation en placeaux labourés et contrôles.



Fig. 5: Species richness in deep ploughed and control plots. $\mathrm{N}=10$, error bars indicate $95 \%$ confidence intervals.

Fig. 5: Richesse spécifique en placeaux labourés et contrôles. 
The program JUICE (TICHY 2002) identifies six species as significantly differentiating the control plots from the ploughed (s. Table 1): Alysicarpus ovalifolius, Amaranthus graezicans, Curcumis melo, Eleusine indica, Mollugo nudicaulis, Sporobulus micropotus and Zornia glochidiata. The grass Aristida spec. was only found in the control plots.
Vegetation of control plots and deep ploughed plots can both be identified as Schoenefeldia gracilis-community. The photos (Fig. 2) illustrate how rainwater was harvested in the plough traces and herbaceous vegetation reappeared around these pools.

Table 1: Floristic composition of control plots and deep ploughed plots* Tableau 1: Composition floristique des placeaux labourés et contrôles

\begin{tabular}{|c|c|c|c|c|c|c|c|c|c|c|c|c|c|c|c|c|c|c|c|c|}
\hline Relevé/Plot No. & 12 & 20 & 13 & 19 & 14 & 15 & 16 & 17 & 11 & 18 & 4 & 5 & 3 & 1 & 2 & 9 & 10 & 8 & 6 & 7 \\
\hline Plot type & \multicolumn{10}{|c|}{ control } & \multicolumn{10}{|c|}{ deep ploughed } \\
\hline Vegetation cover $(\%)$ & $<1$ & 1 & 2 & $<1$ & 1 & 1 & 1 & $<1$ & $<1$ & 1 & 10 & 5 & 15 & 10 & 10 & 8 & 5 & 20 & 15 & 10 \\
\hline Number of species & 4 & 5 & 6 & 5 & 8 & 5 & 5 & 5 & 4 & 3 & 15 & 10 & 14 & 9 & 14 & 10 & 13 & 9 & 11 & 13 \\
\hline \multicolumn{21}{|l|}{$\begin{array}{l}\text { Differential species of deep } \\
\text { ploughed plots }\end{array}$} \\
\hline Alysicarpus ovalifolius & & & & & & & & & & & 2 & 1 & & 1 & 1 & 1 & 2 & 1 & 0,5 & \\
\hline Zornia glochidiata & & & & & & & & & & & 0,5 & 1 & 0,5 & & 0,5 & & & 0,5 & 0,5 & 0,5 \\
\hline Mollugo nudicaulis & & & & & 0,5 & & & & & & 0,5 & 0,5 & 0,5 & 0,5 & 0,5 & 0,5 & 0,5 & & & 0,5 \\
\hline Amaranthus graecizans & & & & & & & & & & & 0,5 & & 0,5 & & 0,5 & 0,5 & 0,5 & & & \\
\hline Cucumis melo & & & & & & & & & & & & 3 & 0,5 & & & 0,5 & & & 0,5 & 0,5 \\
\hline Waltheria indica & & & & & & & & & & & 0,5 & & 0,5 & & & & & & 0,5 & 0,5 \\
\hline Sporobolus microprotus & & & & & & & & & & & 0,5 & & & 0,5 & 1 & & 0,5 & & & \\
\hline \multicolumn{21}{|l|}{$\begin{array}{l}\text { Differential species of } \\
\text { control plots }\end{array}$} \\
\hline Aristida spec. & & 0,5 & & & 0,5 & 0,5 & 0,5 & 0,5 & & & & & & & & & & & & \\
\hline \multicolumn{21}{|l|}{ Companions } \\
\hline Schoenefeldia gracilis & 0,5 & 0,5 & 0,5 & 0,5 & & 0,5 & 0,5 & 0,5 & & & 3 & 0,5 & 5 & 5 & 4 & 5 & 1 & 2 & 5 & 8 \\
\hline Corchorus tridens & & 0,5 & & & & & & & 0,5 & & 1 & 0,5 & 0,5 & 1 & 1 & 0,5 & 0,5 & 0,5 & 0,5 & 0,5 \\
\hline Indigofera senegalensis & 0,5 & & 0,5 & & & & & & 0,5 & & 0,5 & & 1 & 0,5 & 0,5 & 0,5 & 0,5 & 3 & 0,5 & 0,5 \\
\hline Spermacoce chaetocephala & 0,5 & 0,5 & & 0,5 & 0,5 & 0,5 & & & & & & 0,5 & 0,5 & 0,5 & 0,5 & & 1 & & & 0,5 \\
\hline Cassia obtusifolia & & & & & 0,5 & 0,5 & & 0,5 & 0,5 & & 0,5 & & 2 & 2 & & & 2 & 10 & 5 & \\
\hline Panicum laetum & & & 0,5 & 0,5 & 0,5 & & & & & & 0,5 & 0,5 & 1 & & & 0,5 & 0,5 & & 0,5 & 0,5 \\
\hline Acacia tortilis var. raddiana (seedl.) & & & & & & & 0,5 & & & 1 & 0,5 & 0,5 & & & 0,5 & & 0,5 & 0,5 & & 0,5 \\
\hline Ledebouria sudanica & 0,5 & 0,5 & 0,5 & 0,5 & & & & & & & 0,5 & 0,5 & & & & & & & & \\
\hline Tribulus terrestris & & & & & 0,5 & 0,5 & 0,5 & 0,5 & & & & & & & & & 0,5 & & & \\
\hline Cenchrus biflorus & & & & & & & & & & & 0,5 & & 0,5 & & & & & & & \\
\hline Digitaria ciliaris & & & & & 0,5 & & & & & & & & 0,5 & 0,5 & & & & & 0,5 & 0,5 \\
\hline Tragus racemosus & & & 0,5 & 0,5 & & & & 0,5 & & & & & & & & 0,5 & & & & \\
\hline Boerhavia repens viscosa & & & 0,5 & & & & 0,5 & & & & & & & & & & 0,5 & & & \\
\hline Euphorbia forsskalii & & & & & 0,5 & & & & & & 0,5 & & & & 0,5 & & & & & 0,5 \\
\hline Chloris prieurii & & & & & & & & & & & & & & & 0,5 & 0,5 & & 0,5 & & \\
\hline Poaceae indet. & & & & & & & & & 0,5 & 0,5 & & & & & & & & & & \\
\hline Balanites aegyptiaca (seedl.) & & & & & & & & & & 0,5 & & & & & & & & & & \\
\hline Eragrostis pilosa & & & & & & & & & & & & & 0,5 & & & & & & & \\
\hline Eragrostis cilianensis & & & & & & & & & & & & & & & 1 & & & & & \\
\hline Leptadenia hastata (seedl.) & & & & & & & & & & & & & & & 0,5 & & & & & \\
\hline Dactyloctenium aegyptium & & & & & & & & & & & & & & & & & & 0,5 & & \\
\hline Cyperus iria & & & & & & & & & & & & & & & & & & & 0,5 & \\
\hline Echinochloa colona & & & & & & & & & & & & & & & & & & & & 1 \\
\hline
\end{tabular}

\footnotetext{
* Nomenclature follows African Plants Database (http://www.ville-ge.ch/musinfo/bd/cjb/africa/)
} 


\section{Discussion}

As not all soils of the glacis in the study area are incrusted, there are enough reference sites to estimate the vegetation which should be regarded as restoration target. The method described by LANE \& TEXLER (2009) for the absence of reference sites therefore was not needed. As Table 1 and 2 show, deep ploughing proved to be highly effective in restoring vegetation cover as well as species richness. Part of the species richness might be due to the diversity of microhabitats created by the ploughing, but natural Sahelian savanna vegetation of the Schoenefeldia gracilis-type has a comparable species richness (see Table 2). As demanded by HoBbs (2007), the goals were effective and realistic. Also the socio-economic aspects were considered: People in this area are not able to buy fertilizer and they cannot afford to reduce grazing intensity for a longer time in large areas. Compost, recommended by CURTIS \& CLAASSEN (2009) as regeneration tool, also is generally not available in the Sahel. Restoration by grazing management which in many cases is recommendable (PAPANASTASIS 2009) cannot work in this area because it will not lead to a reduction of the incrustion. Considering the implication of climate change, any restoration method has to be checked for its applicability in the changed biophysical conditions of the future (HARRIS et al. 2006). For deep ploughing one can be sure that this method will fit for the Sahelian region also under the conditions predicted by the IPPC.

Our approach to use digital photography appears to be a promising tool when it comes to quantification of vegetation cover, and maybe even biomass (see, e.g., FlomBAUM $\&$ SALA 2009). It is easy to use, time-efficient and precise (which is often not the case with estimation methods: see, e.g., LePS \& HADINCOVA 1992; KLIMES 2003), but is presently not applicable for studies where individual species have to be differentiated.

\section{IMPLICATIONS FOR PRACTICE}

- Our study shows that Vallerani ploughs can be effectively used for restoration of vegetation on incrusted soils in semiarid areas.

- Classification of digital photographs is an easy and accurate way to measure the success of regreening measures.

\section{OUTLOOK}

Our promising results demand for a prolongation of the observation period and an extension of the experiment to other Sahelian areas. Considering the recent sahelisation of large parts of the Sudanian zone (WITTIG et al. 2006, 2007), the method should also be tested in Subsahelian and North Sudanian areas.

The regreening achieved in the experiments is only a first step. For many areas of the Sahel, the final aim should be the regeneration of the water harvesting tiger bush. To reach this aim the exclusion of grazing for some years is a conditio sine qua non.
Table 2: Floristic composition* (\% constancy) of incrusted plots (1), deep ploughed (formerly incrusted) plots (2) and of not incrusted areas of the glacis (3)

Tableau 2: Composition floristique (\% constance) des placeaux encroûtés (1), labourés (2) et des aires de glacis non-encroûtés.

\begin{tabular}{|c|c|c|c|}
\hline Plot type & 1 & 2 & 3 \\
\hline Number of plots & 10 & 10 & 69 \\
\hline Mean vegetation cover (\%) & $<1$ & 11 & 64 \\
\hline Mean species number & 5 & 11 & 13 \\
\hline Schoenefeldia gracilis & 70 & 100 & 96 \\
\hline Panicum laetum & 30 & 70 & 59 \\
\hline Spermacoce chaetocephala & 50 & 60 & 68 \\
\hline Corchorus tridens & 10 & 100 & 39 \\
\hline Cassia obtusifolia & 40 & 60 & 14 \\
\hline Acacia tortilis var. raddiana (seedling) & 20 & 60 & 14 \\
\hline Digitaria ciliaris & 10 & 40 & 33 \\
\hline Mollugo nudicaulis & 10 & 80 & 36 \\
\hline Tribulus terrestris & 40 & 10 & 46 \\
\hline Tragus racemosus & 30 & 10 & 46 \\
\hline Boerhavia repens viscosa & 20 & 10 & 38 \\
\hline Ledebouria sudanica & 40 & 20 & 9 \\
\hline Leptadenia hastata (seedling) & 30 & 10 & 12 \\
\hline Euphorbia forsskalii & 10 & 30 & 13 \\
\hline Alysicarpus ovalifolius & & 80 & 75 \\
\hline Zornia glochidiata & & 70 & 65 \\
\hline Enteropogon prieurii & & 30 & 62 \\
\hline Cenchrus biflorus & & 20 & 54 \\
\hline Indigofera senegalensis & & 90 & 17 \\
\hline Waltheria indica & & 40 & 4 \\
\hline Sporobolus microprotus & & 40 & 4 \\
\hline Amaranthus graecizans & & 50 & 1 \\
\hline Dactyloctenium aegyptium & & 10 & 84 \\
\hline Eragrostis pilosa & & 10 & 32 \\
\hline Aristida spec. / A. mutabilis & 50 & & 29 \\
\hline Cucumis melo & & 50 & \\
\hline Tragus berteronianus & & & 30 \\
\hline Indigofera aspera & & & 30 \\
\hline Aristida funiculata & & & 29 \\
\hline
\end{tabular}

* only species with a constancy $>20 \%$

sources: 1 and 2: this paper (Table 1);

3: MÜLleR (2003; Table 17, No. 24-92)

When the tiger bush is restored it will not only serve as a water harvesting system (VALENTIN \& D'HERBÈs 1999), but can be used for grazing and as source for wood. However, to avoid re-degradation, a sustainable management has to be implemented. Regeneration of tiger bush may be also of interest for carbon-sequestration, because woody biomass production has proved to equal that of the forest in more humid southern zones and to exceed that of industrial plantations in the same area (LEPRUN 1999). 


\section{ACKNOWLEDGEMENTS}

We thank Mr. Amadou Boureima for the permission to study the restoration site of ADRA in the South of Gorom-Gorom and for an introduction into the site and the methods applied, Gaëlle Bocksberger for translating the abstract into French, Dick Byer for correcting the English and Dr. Ute Becker for help with the statistics.

\section{REFERENCES}

Albert K-D, Müller J, Ries JB, \& MarzolfF I (2004): Aktuelle Landdegradation in der Sahelzone Burkina Fasos. - In Albert KD, LöHr D \& NeumanN K (eds.): Mensch und Natur in Westafrika. Wiley-VCH, 289-330.

Braun-Blanquet J (1964): Pflanzensoziologie - Grundzüge der Vegetationskunde. - 3. Aufl. Springer, Wien.

Claude J, Grouzis M \& Milleville P (1991): Un espace sahélien. La Mare d'Oursi, Burkina Faso.- ORSTOM, Paris.

Curtis MJ \& ClaAssen VP (2007): Regenerating topsoil functionality in four drastically disturbed soil types by compost incorporation. - Restoration Ecol. 17: 24-32.

Flombaum P \& Sala OE (2009): Cover is a good predictor of aboveground biomass in arid systems. - J. Arid Environ. 73: 597-598.

Ganaba S, Bayala J, Yaméogo KM, Yaméogo JT \& OudBA J-M (2006): Impact des aménagements anti-erosif sur la phénologie, la transpiration et la productivité fruitière ligneuses en zone subsahélienne du Burkina Faso. - Etudes flor. vég. Burkina Faso 10: 49-62.

Harris JA, Hobbs RJ, Higgs E \& Aronson J (2006): Ecological Restoration and Global Climate Change. - Restoration Ecol. 14: 170-176.

HobBs RJ (2007): Setting effective and realistic restoration goals: Key directions for research. - Restoration Ecol. 15: 354-357.

KLimes, L. (2003): Scale-dependent variation in visual estimates of grassland plant cover. - J. Veg. Sci. 14: 815-821.

LANE CP \& TEXLER HD (2009): Generating quantitative regional plant community descriptions for restoration. - Restoration Ecol. 17: 42-50.

LEPRUN JC (1999): The influences of ecological factors on tiger bush and dotted bush patterns along a gradient from Mali to nothern Burkina Faso. - Catena 37: 25-44.

Leps J \& Hadincova V (1992): How Reliable Are Our Vegetation Analyses. - J. Veg. Sci. 3: 119-124.

LONDO G (1976): The decimal scale for releves of permanent quadrats. - Vegetatio 33: 61-64.

Malagnoux M (2009): Degraded Arid Land Restoration for Afforestation and Agro-Silvo-Pastoral Production through New Water Harvesting Mechanized Technology. - In LeE C $\&$ SchaAf T (eds.): The Future of Drylands. Springer, Netherlands, 269-282.
This study was financially supported by the German Ministry of Education and Research (BMBF) in the frame of the BIOTA project (FKZ: 01 LC 0617D1). We thank the German Federal state of Hesse for funding the Biodiversity and Climate Research Institute (BiK-F).

Mando A, BrussaArd L \& Stroosnijder L (1999): Termite- and mulch-mediated rehabilitation of vegetation on crusted soil in West Africa. - Restoration Ecol. 7: 33-41.

MÜLLER JV (2003): Zur Vegetationsökologie der Savannenlandschaften im Sahel Burkina Fasos. - PhD thesis, J.W. Goethe-University, Frankfurt am Main.

Nielsen JØ \& Rennberg A (2010): Temporality and the problem with singling out climate as a current driver of change in a small West African village. - J. Arid Environ. 74 (4): 464-474

OuEdRAogo RL, GuinKo S \& Wittig R (2005): La vegetation aquatique et semi-aquatique de la Mare aux Hippopotames et des Mares d'Oursi et Yomboli (Burkina Faso). Etudes flor. vég. Burkina Faso 9:19-33.

PAPANASTASIS VP (2009): Restoration of degraded grazing lands through grazing management: Can it work? - Restoration Ecol. 17: 441-445.

PARI L \& ANTINORI P (2001): Production of biomass in the Mediterranean area with the microbasins mechanized technique (Vallerani System) to fight desertification. - In KYRITSIS S (ed.): Proc. 1st World Conference on Biomass for Energy and Industry, Sevilla, Spain, 5-9 June 2000. James \& James Ltd., London, 1963-1965.

Pielou EC (1969): An Introduction to Mathematical Ecology. - John Wiley and Sons, New York.

Roose E, Kabore V \& Guenat C (1999): Zaï practice: A West African traditional rehabilitation system for semiarid degraded lands, a case study in Burkina Faso.- Arid Soil Res. Rehab. 13: 343-355.

Sawadogo H, Bock L, Lacroix D \& Zombre NP (2008): Restoring soil potentialities using zaï and compost in Yatenga (Burkina Faso). - Biotech. Agron. Soc. Environ. 12: 279-290.

Schmidt M (2006): Pflanzenvielfalt in Burkina Faso Analyse, Modellierung und Dokumentation. - PhD thesis, J.W.Goethe-University, Frankfurt am Main.

Sørensen T (1948): A method of establishing groups of equal amplitude in plant sociology based on similarity of species and its application to analyses of the vegetation on Danish commons. - Biol. Skr. Dan. Vid. Selsk. 5: 1-34.

SPSS (2006): SPSS 15.0 for Windows and Smart-Viewer. SPSS, Chicago, IL.

TICHÝ L (2002): JUICE, software for vegetation classification. - J. Veg. Sci. 13: 451-453. 
VAlentin C \& D`Herbès JM (1999): Niger tiger bush as a natural water harvesting system. - Catena 37: 231-256.

White F (1983): The vegetation of Africa. A descriptive memoire to accompany the Unesco/Aetfat/Unso vegetation map of Africa. - Unesco Natural Resources Research 20: 1356.

Wittig R, Hahn-Hadjali K, Krohmer J, Müller J \& SieglstetTer R (2002): La végétation actuelle des savanes du Burkina Faso et du Bénin - sa signification pour l'homme et la modification de celle-ci par l'homme (aperçu des résultats d'un projet de recherche duré des années). - Etudes flor. vég. Burkina Faso 7: 3-16.

Wittig R, Hahn-Hadjali K, König K, Schmidt M, SzarZYNSKI J \& THIOMBIANO A (2006): Dynamik von Flora und Vegetation in der westafrikanischen Sudanzone am Beispiel von Burkina Faso. - Ber. Reinh.-Tüxen-Ges. 18: 57-68.

Wittig, R., König, K., Schmidt, M., \& J. Szarzynski (2007): A Study of Climate Change and Anthropogenic Impacts in West Africa. - Environ. Sci. Poll. Res. 14: 182-189.

Zougmore, R, ZiDA Z \& KAMBOU NF (2003): Role of nutrient amendments in the success of half-moon soil and water conservation practice in semiarid Burkina Faso. - Soil Tillage Res. 71: 143-149.

\section{AdDREsSES OF THE AUTHORS}

Dr. Marco Schmidt

Prof. Dr. Georg Zizka

Research Institute Senckenberg \&

Institute of Ecology, Evolution and Diversity

Goethe-Universität

Senckenberganlage 25

D-60325 Frankfurt am Main

Germany

eMail:marco.schmidt@senckenberg.de

eMail: georg.zizka@senckenberg.de

\section{Dr. Karen Hahn}

Prof. Dr. Rüdiger Wittig

Institute of Ecology, Evolution and Diversity

Goethe-Universität

Siesmayerstraße 70

D-60323 Frankfurt am Main

Germany

eMail: r.wittig@bio.uni-frankfurt.de eMail: karen.hahn@bio.uni-frankfurt.de

\section{Dr. Konstantin König}

BiK-F

Biodiversity and Climate Research Centre-

Mertonstraße 17-21

D-60325 Frankfurt am Main

eMail: k.koenig@cgiar.org 